\title{
Fuzzy logic for preconstruction project planning index
}

\begin{abstract}
Planning comes in the first place and can be considered as one of the most important factors in managing construction projects. This research aims to introduce a Quality Index for Preconstruction Project Planning (QIPPP). The development of the QIPPP model follows four steps. First, collecting factors affecting the preconstruction project planning (PCPP) through a comprehensive literature review. Second, identifying the most important factor using Delphi technique. Third, assigning relative weights to each factor using the Analytical Hierarchy Process (AHP). Fourth, developing and validating a precise model for QIPPP. This model helps the user to predict the percentage of matching between the preconstruction plan and the actual values after finishing the whole project. Both deterministic model and fuzzy model have been developed where the fuzzy model produces better results than the deterministic model. This research uses project duration as a bench mark to evaluate the model by comparing the model result with two case studies.
\end{abstract}

Keywords: preconstruction project planning, planning quality index, delphi rounds, analytical hierarchy process, fuzzy logic
Volume 5 Issue I - 2019

\author{
Ahmed Elyamany, Eman F Abdelsalam, \\ Hossam El-din Hosni \\ Department of Construction and Utilities, Zagazig \\ University, Egypt
}

Correspondence: Haytham H EIMousalami, Department of construction and utilities, faculty of Engineering, Zagazig University, Egypt, Email Haythamelmousalami2014@gmail.com

Received: December 18, 2018 | Published: January 04, 2019

\section{Introduction}

Overruns in project schedule and cost can cause serious financial risk to both contractors and owners. ${ }^{1}$ A significant cause for schedule delays and cost overruns in most large-scale projects may be found in unrealistic baseline plans. ${ }^{2}$ The lack of preconstruction planning is surely the major failure of contractors in the entire construction industry. So, the main stage in the project must be the planning stage. There is no available tool to measure the quality of planning or to predict how successful it is. The key objective of this study is to develop a reliable precise tool to measure the quality of planning at preconstruction project stage. The objectives of this research are:

a. Identifying factors affecting preconstruction project planning.

b. Developing a precise model for a Quality Index for Preconstruction Project Planning (QIPPP).

\section{Methodology}

I. The methodology of this research can be summarized as follows:

II. Identify factors that affect PCPP from Literature.

III. Use Delphi technique to obtain a short list of the most effective factors.

IV. Use Analytic Hierarchy Process (AHP) to obtain factors weights in QIPPP model.

V. Develop a QIPPP model where three models have been developed as the following:

VI. Deterministic model

VII. Fuzzy summation model

VIII. Fuzzy-Fuzzy model

IX. Validate the QIPPP models and select the most accurate model.

\section{Literature review}

Integration of stakeholders at the preconstruction planning stage ensures project success and cost saving at the early stage of green building projects. ${ }^{3}$ Quality planning is a disciplined process to ensure that a structured sequence of activities is completed. These activities will ensure that an organization can provide a quality product on time, at the lowest cost and to the customer's custom specifications. ${ }^{4,5}$ Defined that planning is a process of deciding the following: (1) what activity to be completed; (2) how the activity should be completed; (3) who should complete the activity; and (4) when should the activity be completed prior to when the activity is to be performed. ${ }^{5,6}$ Moreover, The Plumbing-Heating-Cooling Contractors (PHCC) National Association have listed the benefits of preconstruction planning as the following: greater project control, increased project organization, better worker productivity, improved safety record, and increased project profitability. Construction planning is necessary to account for all the variables and situations that may arise during a construction project. In addition, Planning for construction allows a contractor to be proactive rather than reactive to the problems as they arise where that planning helps contractor to controls the direction of the project and minimize the impact of problems. ${ }^{7}$ Preconstruction planning is a comprehensive set of procedures a contractor do immediately after contract award and right before construction starts. ${ }^{8}$ One of the most important tasks in construction planning is to prepare the time plan. ${ }^{9}$ The time plan is an essential part of the planning to assure that the project is completed on time..$^{10}$ divided construction planning into three levels. The first level is strategic planning which focuses on the organizations long-term objectives and vision. The second level is the tactical planning where the aim is to form a structure for the organization operation. The third level is the operational planning which aims to reach the short-term objectives of the project. The operational planning in a construction project is represented by weekly or working plans. 


\section{Factors affecting preconstruction project planning (PCPP)}

This research conducted seventy-seven factors affecting PCPP, $30 \%$ of reviewed researches mention that project scope definition is one of the factors affecting PCPP. For instance, ${ }^{11}$ found in another previous studies, ${ }^{12,13}$ that success during the detailed design, construction, and startup phases of a project depends highly on the level of effort expended during the scope definition phase. While $20 \%$ of reviewed researches mention that accurate work flow planning, design errors and change orders, experience and intuition of the project team members and resource availability are affecting PCPP. Whereas, Doloi ${ }^{14}$ made a research concluded that accurate project planning and monitoring is one of eight critical factors extracted from a total of 36 selected attributes based on the responses received from clients, consultants and contractors in Cost Overruns and Failure in
Project the overall sample. One of those eight factors was (accurate project planning and monitoring), according to contractors point of view accurate work flow planning is affecting accurate project planning and monitoring. Son \& Rojas ${ }^{15}$ Conducted that "design errors and change orders" is one of the factors that affection project scheduling. To make good decisions, both experience from the previous contracts and the knowledge of customers' needs and local conditions must be exploited. ${ }^{14} \mathrm{~A}$ knowledge base containing all the experience gathered by the organization while executing previous projects could be an advantage. Otherwise, the decision process can be based on experience and intuition of the project team members only. Resource availability is one of the important constraints to take into account to obtain feasible scheduling Masmoudi \& Hait. ${ }^{16}$ The rest of factors mentioned in $11.1 \%$ from the reviewed researches. All of those seventy-seven factors shown in Table 1.

Table I Factors collected from previous studies

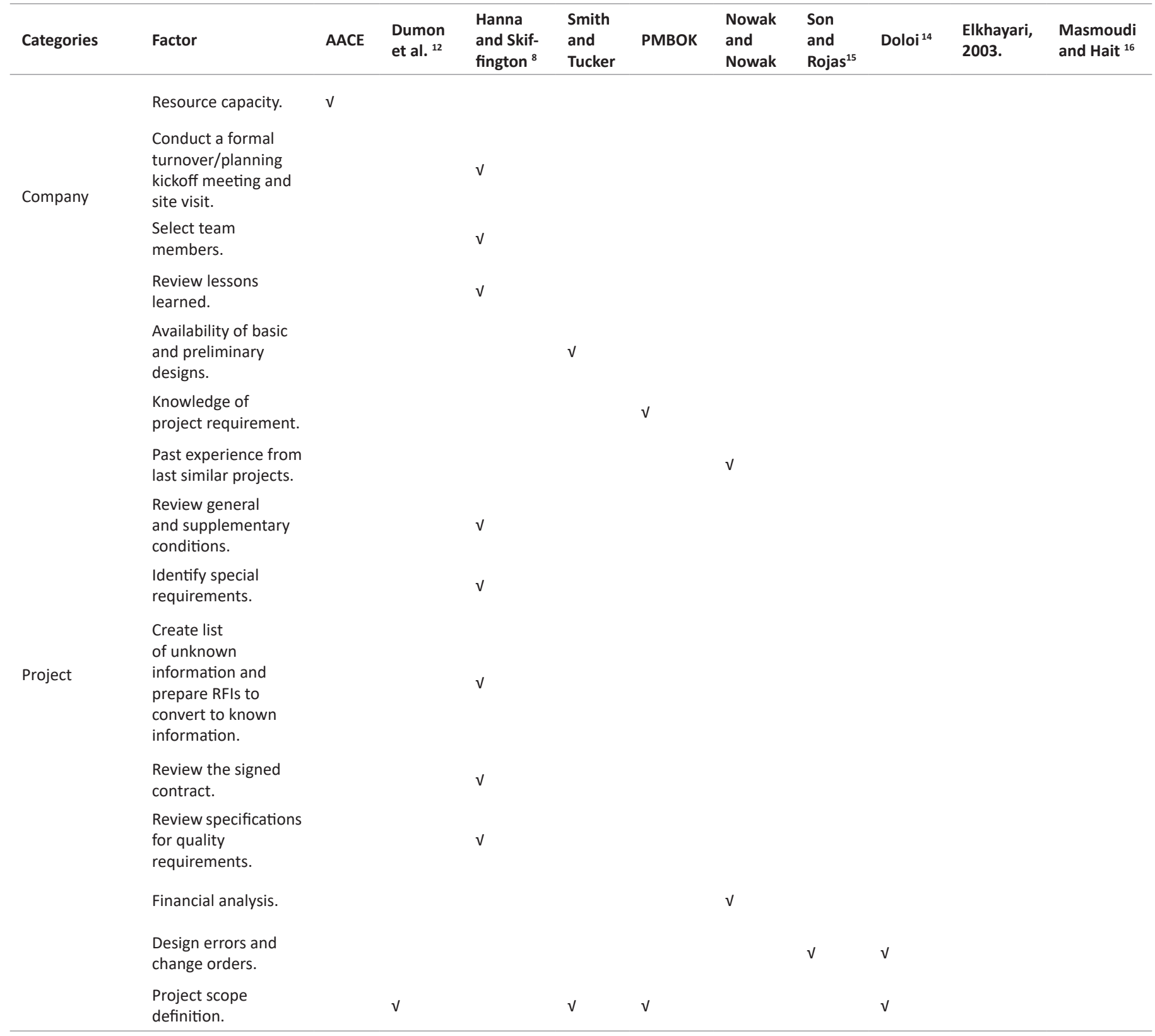


Table Continued...

\begin{tabular}{|c|c|c|c|c|c|c|c|c|c|c|c|}
\hline Categories & Factor & AACE & $\begin{array}{l}\text { Dumon } \\
\text { et al. } 12\end{array}$ & $\begin{array}{l}\text { Hanna } \\
\text { and Skif- } \\
\text { fington }^{8}\end{array}$ & $\begin{array}{l}\text { Smith } \\
\text { and } \\
\text { Tucker }\end{array}$ & РМВОК & $\begin{array}{l}\text { Nowak } \\
\text { and } \\
\text { Nowak }\end{array}$ & $\begin{array}{l}\text { Son } \\
\text { and } \\
\text { Rojas }^{15}\end{array}$ & Doloi $^{14}$ & $\begin{array}{l}\text { Elkhayari, } \\
2003 .\end{array}$ & $\begin{array}{l}\text { Masmoudi } \\
\text { and Hait }{ }^{16}\end{array}$ \\
\hline \multirow[t]{17}{*}{ Engineer Staff } & $\begin{array}{l}\text { Details of resources } \\
\text { required. }\end{array}$ & & & & & & & & $v$ & & \\
\hline & $\begin{array}{l}\text { Accurate work flow } \\
\text { planning. }\end{array}$ & & & & & $v$ & & & $v$ & & \\
\hline & $\begin{array}{l}\text { Identify and price } \\
\text { substitute materials } \\
\text { and equipment. }\end{array}$ & & & $v$ & & & & & & & \\
\hline & $\begin{array}{l}\text { Submit substitution } \\
\text { request to owner/ } \\
\text { CM/GC. }\end{array}$ & & & v & & & & & & & \\
\hline & $\begin{array}{l}\text { Discuss alternative } \\
\text { duct routes. }\end{array}$ & & & $\checkmark$ & & & & & & & \\
\hline & $\begin{array}{l}\text { Identify potential } \\
\text { cost savings. }\end{array}$ & & & V & & & & & & & \\
\hline & $\begin{array}{l}\text { Review } \\
\text { subcontractor bids, } \\
\text { qualifications, and } \\
\text { current work load. }\end{array}$ & & & $v$ & & & & & & & \\
\hline & $\begin{array}{l}\text { Review scope } \\
\text { of work with } \\
\text { subcontractors. }\end{array}$ & & & V & & & & & & & \\
\hline & $\begin{array}{l}\text { Write contracts } \\
\text { for selected } \\
\text { subcontractors. }\end{array}$ & & & V & & & & & & & \\
\hline & $\begin{array}{l}\text { Obtain and review } \\
\text { owner/CM/GC } \\
\text { (owner/construction } \\
\text { management/ } \\
\text { general contractor) } \\
\text { schedule. }\end{array}$ & & & v & & & & & & & \\
\hline & $\begin{array}{l}\text { Identify mobilization } \\
\text { /demobilization } \\
\text { dates. }\end{array}$ & & & V & & & & & & & \\
\hline & $\begin{array}{l}\text { Identify and } \\
\text { establish delivery } \\
\text { dates for long lead } \\
\text { time items. }\end{array}$ & & & v & & & & & & & \\
\hline & $\begin{array}{l}\text { Identify construction } \\
\text { equipment delivery } \\
\text { dates. }\end{array}$ & & & v & & & & & & & \\
\hline & $\begin{array}{l}\text { Identify work by } \\
\text { others that directly } \\
\text { impacts sheet metal } \\
\text { activities. }\end{array}$ & & & V & & & & & & & \\
\hline & $\begin{array}{l}\text { Develop a } \\
\text { coordination } \\
\text { schedule with other } \\
\text { subcontractors. }\end{array}$ & & & v & & & & & & & \\
\hline & $\begin{array}{l}\text { Establish project } \\
\text { subcontractor start/ } \\
\text { finish date. }\end{array}$ & & & v & & & & & & & \\
\hline & $\begin{array}{l}\text { Review specifications } \\
\text { for quality } \\
\text { requirements. } \\
\text { Inform workers of } \\
\text { required quality } \\
\text { standards. }\end{array}$ & & & $v$ & & & & & & & \\
\hline
\end{tabular}


Table Continued..

\begin{tabular}{|c|c|c|c|c|c|c|c|c|c|c|c|}
\hline Categories & Factor & AACE & $\begin{array}{l}\text { Dumon } \\
\text { et al. }{ }^{12}\end{array}$ & $\begin{array}{l}\text { Hanna } \\
\text { and Skif- } \\
\text { fington }{ }^{8}\end{array}$ & $\begin{array}{l}\text { Smith } \\
\text { and } \\
\text { Tucker }\end{array}$ & РMBOK & $\begin{array}{l}\text { Nowak } \\
\text { and } \\
\text { Nowak }\end{array}$ & $\begin{array}{l}\text { Son } \\
\text { and } \\
\text { Rojas }^{15}\end{array}$ & Doloi $^{14}$ & $\begin{array}{l}\text { Elkhayari, } \\
2003 .\end{array}$ & $\begin{array}{l}\text { Masmoudi } \\
\text { and Hait }{ }^{16}\end{array}$ \\
\hline & $\begin{array}{l}\text { Review safety } \\
\text { lessons learned from } \\
\text { other jobs. }\end{array}$ & & & $v$ & & & & & & & \\
\hline & $\begin{array}{l}\text { Review safety and } \\
\text { OSHA (Occupational } \\
\text { Safety and Health } \\
\text { Administration) } \\
\text { requirements. }\end{array}$ & & & $v$ & & & & & & & \\
\hline & $\begin{array}{l}\text { Walk the site to } \\
\text { search for hazards } \\
\text { before construction } \\
\text { begins. }\end{array}$ & & & $v$ & & & & & & & \\
\hline & $\begin{array}{l}\text { Inform workers } \\
\text { of required safety } \\
\text { standards. }\end{array}$ & & & $v$ & & & & & & & \\
\hline & $\begin{array}{l}\text { Determine log lead- } \\
\text { time items. }\end{array}$ & & & $v$ & & & & & & & \\
\hline & $\begin{array}{l}\text { Contract material } \\
\text { and equipment } \\
\text { suppliers. }\end{array}$ & & & $v$ & & & & & & & \\
\hline & $\begin{array}{l}\text { Order/prepare shop } \\
\text { drawings for long } \\
\text { lead-time items. }\end{array}$ & & & $v$ & & & & & & & \\
\hline & $\begin{array}{l}\text { Develop purchase } \\
\text { orders for materials } \\
\text { and equipment. }\end{array}$ & & & $v$ & & & & & & & \\
\hline & $\begin{array}{l}\text { Review estimated } \\
\text { work hours. }\end{array}$ & & & $v$ & & & & & & & \\
\hline & $\begin{array}{l}\text { Develop a sequence } \\
\text { of work and create a } \\
\text { schedule of values. }\end{array}$ & & & $v$ & & & & & & & \\
\hline & $\begin{array}{l}\text { Prepare a manpower } \\
\text { loading chart. }\end{array}$ & & & $v$ & & & & & & & \\
\hline & $\begin{array}{l}\text { Develop CAD } \\
\text { drawings to identify } \\
\text { conflicts and } \\
\text { coordinate work. }\end{array}$ & & & $\mathrm{V}$ & & & & & & & \\
\hline & $\begin{array}{l}\text { Identify materials } \\
\text { and systems that can } \\
\text { be prefabricated. }\end{array}$ & & & $v$ & & & & & & & \\
\hline & $\begin{array}{l}\text { Identify shop } \\
\text { fabrication } \\
\text { requirements and } \\
\text { prepare a schedule. }\end{array}$ & & & $v$ & & & & & & & \\
\hline & $\begin{array}{l}\text { Schedule delivery } \\
\text { of prefabricated } \\
\text { materials. }\end{array}$ & & & $v$ & & & & & & & \\
\hline & $\begin{array}{l}\text { Identify field } \\
\text { reporting procedures } \\
\text { and create project } \\
\text { file. }\end{array}$ & & & $v$ & & & & & & & \\
\hline & $\begin{array}{l}\text { Review FRI } \\
\text { (Fire-Rescue } \\
\text { International) } \\
\text { and change order } \\
\text { procedures. }\end{array}$ & & & $v$ & & & & & & & \\
\hline
\end{tabular}


Table Continued...

\begin{tabular}{|c|c|c|c|c|c|c|c|c|c|c|c|}
\hline Categories & Factor & AACE & $\begin{array}{l}\text { Dumon } \\
\text { et al. }{ }^{12}\end{array}$ & $\begin{array}{l}\text { Hanna } \\
\text { and Skif- } \\
\text { fington }^{8}\end{array}$ & $\begin{array}{l}\text { Smith } \\
\text { and } \\
\text { Tucker }\end{array}$ & РМBOK & $\begin{array}{l}\text { Nowak } \\
\text { and } \\
\text { Nowak }\end{array}$ & $\begin{array}{l}\text { Son } \\
\text { and } \\
\text { Rojas }^{15}\end{array}$ & Doloi ${ }^{14}$ & $\begin{array}{l}\text { Elkhayari, } \\
2003 .\end{array}$ & $\begin{array}{l}\text { Masmoudi } \\
\text { and Hait }{ }^{16}\end{array}$ \\
\hline & $\begin{array}{l}\text { Review billing } \\
\text { procedures and } \\
\text { prepare a billing } \\
\text { schedule. }\end{array}$ & & & $v$ & & & & & & & \\
\hline & $\begin{array}{l}\text { Receive storage } \\
\text { approval from } \\
\text { owner/CM/GC. }\end{array}$ & & & $v$ & & & & & & & \\
\hline & $\begin{array}{l}\text { Schedule delivery } \\
\text { of prefabricated } \\
\text { materials. }\end{array}$ & & & $v$ & & & & & & & \\
\hline & $\begin{array}{l}\text { Identify field } \\
\text { reporting procedures } \\
\text { and create project } \\
\text { file. }\end{array}$ & & & $v$ & & & & & & & \\
\hline & $\begin{array}{l}\text { Review FRI } \\
\text { (Fire-Rescue } \\
\text { International) } \\
\text { and change order } \\
\text { procedures. }\end{array}$ & & & $v$ & & & & & & & \\
\hline & $\begin{array}{l}\text { Review billing } \\
\text { procedures and } \\
\text { prepare a billing } \\
\text { schedule. }\end{array}$ & & & $v$ & & & & & & & \\
\hline & $\begin{array}{l}\text { Receive storage } \\
\text { approval from } \\
\text { owner/CM/GC. }\end{array}$ & & & $v$ & & & & & & & \\
\hline & $\begin{array}{l}\text { Consideration of } \\
\text { buildability and } \\
\text { requirements } \\
\text { of specialized } \\
\text { resources. }\end{array}$ & & & & & & & & v & & \\
\hline & $\begin{array}{l}\text { Agreement on } \\
\text { appropriate project } \\
\text { budget and delivery } \\
\text { timeframe. }\end{array}$ & & & & & & & & v & & \\
\hline & $\begin{array}{l}\text { Clear process of } \\
\text { project control. }\end{array}$ & & & & & & & & v & & \\
\hline & $\begin{array}{l}\text { Clear change request } \\
\text { protocol. }\end{array}$ & & & & & & & & $\checkmark$ & & \\
\hline & $\begin{array}{l}\text { Monitoring and } \\
\text { status reporting } \\
\text { protocols. }\end{array}$ & & & & & & & & v & & \\
\hline & $\begin{array}{l}\text { Clear understanding } \\
\text { of the project scope. }\end{array}$ & & & & & & & & v & & \\
\hline & $\begin{array}{l}\text { Knowledge of } \\
\text { customers' needs. }\end{array}$ & & & & & & v & & & & \\
\hline & $\begin{array}{l}\text { Understanding the } \\
\text { design. }\end{array}$ & & & & & & & & $v$ & & \\
\hline & $\begin{array}{l}\text { Construction } \\
\text { methods and } \\
\text { techniques. } \\
\text { Complexity of on- } \\
\text { site construction } \\
\text { activities. } \\
\text { Experience and } \\
\text { intuition of the } \\
\text { project team } \\
\text { members. }\end{array}$ & & & & & & $\mathrm{V}$ & & $\begin{array}{l}v \\
v\end{array}$ & & \\
\hline
\end{tabular}


Table Continued...

\begin{tabular}{|c|c|c|c|c|c|c|c|c|c|c|c|}
\hline Categories & Factor & AACE & $\begin{array}{l}\text { Dumon } \\
\text { et al. }{ }^{12}\end{array}$ & $\begin{array}{l}\text { Hanna } \\
\text { and Skif- } \\
\text { fington }^{8}\end{array}$ & $\begin{array}{l}\text { Smith } \\
\text { and } \\
\text { Tucker }\end{array}$ & РМВОК & $\begin{array}{l}\text { Nowak } \\
\text { and } \\
\text { Nowak }\end{array}$ & $\begin{array}{l}\text { Son } \\
\text { and } \\
\text { Rojas }^{15}\end{array}$ & Doloi $^{14}$ & $\begin{array}{l}\text { Elkhayari, } \\
2003 .\end{array}$ & $\begin{array}{l}\text { Masmoudi } \\
\text { and Hait }{ }^{16}\end{array}$ \\
\hline \multirow[t]{8}{*}{ Site Conditions } & $\begin{array}{l}\text { Receive storage } \\
\text { approval from } \\
\text { owner/CM/GC. }\end{array}$ & & & V & & & & & & & \\
\hline & $\begin{array}{l}\text { Discuss storage, site } \\
\text { layout, and handling } \\
\text { of materials and } \\
\text { systems. }\end{array}$ & & & V & & & & & & & \\
\hline & $\begin{array}{l}\text { Establish procedures } \\
\text { for receiving, } \\
\text { storing, and handling } \\
\text { material. }\end{array}$ & & & $v$ & & & & & & & \\
\hline & $\begin{array}{l}\text { Identify construction } \\
\text { equipment required. }\end{array}$ & & & $\mathrm{V}$ & & & & & & & \\
\hline & Resource availability. & & & & & & & & & v & v \\
\hline & $\begin{array}{l}\text { Late material } \\
\text { delivery. }\end{array}$ & & & & & & & $v$ & & & \\
\hline & $\begin{array}{l}\text { Shortage of labor } \\
\text { and unskilled labor. }\end{array}$ & & & & & & & $\mathrm{V}$ & & & \\
\hline & $\begin{array}{l}\text { Bad weather } \\
\text { conditions. }\end{array}$ & & & & & & & $\mathrm{V}$ & & & \\
\hline
\end{tabular}

\section{Data collection and analysis}

Factors are identified from previous studies, screened and analyzed in two stages. Stage one, Delphi technique is conducted to produce a short list of factors affecting preconstruction project planning. Stage two, a questionnaire survey has been conducted to collect experts' opinions about factors affecting the preconstruction project planning and obtain factors' weights in the QIPPP model using the Analytic Hierarchy Process (AHP).

\section{Delphi technique}

The Delphi process involves a series of questionnaire rounds, each followed by iterative analysis and feedback. The process concludes when a predefined level of consensus is reached. ${ }^{17}$ In this research, the consensus reached when experts return questionnaires without adding or eliminating any factor. According to Clayton ${ }^{18}$ only 5 to 10 experts are needed. Here, the surveyed panel consists of 8 experienced engineers. The classification of the surveyed panel experiences is shown in Table 2. Questionnaires are sent by mail to the surveyed panel in three consecutive rounds. The first round consists of seventyseven factors listed in Table 1. The surveyed experts are asked to:

a. Rate each factor using a five-point Likert scale (1=Extremely Ineffective, $2=$ Moderately Ineffective, $3=$ Neutral, $4=$ Moderately Effective, 5= Extremely Effective)

b. Add factors other than listed, if any.

c. Modify factors, if any.

d. Add suggestions, if any.

The result of the first round eliminated 47 factors out of 77 . Experts add two new factors; "financial capacity" in company category and "complexity of project" in project category, which increase factors to 32 . The result of the second round eliminated 17 factors from the previous 32 factors of the first round and left 15 factors. The consensus is reached in the third round as the experts left the same factors without eliminating or adding as shown in Table 3. Next, AHP is utilized to find weights of these factors and develop the quality index for preconstruction project planning Model Table 2.

Table 2 Classification of the surveyed experts based on their experience

\begin{tabular}{llllll}
$\begin{array}{l}\text { Years of } \\
\text { experience }\end{array}$ & $\begin{array}{l}\text { Project } \\
\text { managers }\end{array}$ & $\begin{array}{l}\text { Planning } \\
\text { engineer }\end{array}$ & $\begin{array}{l}\text { Site } \\
\text { engineer }\end{array}$ & Total & \% \\
\hline$<10$ years & - & 1 & 1 & 2 & 25 \\
$\geq 10$ years and $>15$ & - & 2 & 1 & 3 & 37.5 \\
$\geq 15$ years & 1 & 2 & - & 3 & 37.5 \\
\hline
\end{tabular}

\section{AHP}

AHP is a set of axioms that carefully delimits the scope of the problem environment. ${ }^{19}$ It is based on the well-defined mathematical structure of consistent matrices and their associated right eigenvector's ability to generate true or approximate weights. ${ }^{20,21}$ The AHP methodology compares criteria, or alternatives with respect to the main criterion, in a natural, and pair wise mode. AHP uses a fundamental scale of absolute numbers. The fundamental scale has been shown to be a scale that captures individual preferences with respect to quantitative and qualitative attributes just as well or better than other scales. ${ }^{20,21}$

\section{AHP Questionnaire}

The AHP questionnaire aims to determine factors' in QIPPP model. 135 questionnaires are sent to the experts. Only 73 responses are received back; 29 are incomplete and 44 are complete. The percentage of completed surveys is $32.6 \%$. The respondents' job classification are; $11.1 \%$ are Project managers, $66.7 \%$ are planning engineers while $22.2 \%$ are site engineers. Questionnaires statistics are shown in Table 4 , while Table 5 shows the distribution of respondents' experiences. 
Table 3 Factors after the Third round

\begin{tabular}{lll}
\hline Category & \multicolumn{2}{l}{ Factor } \\
1.1 & The financial capacity (Assets, cash flow, etc.). \\
1.2 & Resource capacity. \\
& 1.3 & Select team members. \\
\hline 2. Project (C2) & 2.1 & Project scope definition. \\
& 2.2 & Project Complexity. \\
& 2.3 & Past experience from last similar projects. \\
& 2.4 & Financial analysis. \\
\hline 3.1 & Clear understanding of the project scope. \\
\hline 3.2 & Accurate work flow planning. \\
& 3.3 & Clear process of project control. \\
& 3.4 & Clear change request protocol. \\
3.5 & Experience and intuition of the project team members. \\
\hline 4.1 & Resource availability. \\
4.2 & Late material delivery. \\
\hline 4.3 & Bad weather conditions. \\
\hline 4ite conditions (C4) & &
\end{tabular}

Table 4 AHP Questionnaire and statistics

\begin{tabular}{llllll}
\hline $\begin{array}{l}\text { Construction } \\
\text { projects experts }\end{array}$ & $\begin{array}{l}\text { Distributed } \\
\text { questioners }\end{array}$ & $\begin{array}{l}\text { Returned } \\
\text { questioners }\end{array}$ & $\begin{array}{l}\text { uncompleted } \\
\text { questioners }\end{array}$ & $\begin{array}{l}\text { completed } \\
\text { questioners }\end{array}$ & $\begin{array}{l}\text { \% completed } \\
\text { questioners }\end{array}$ \\
\hline Project managers & 15 & 10 & 5 & 5 & 33.3 \\
Planning engineer & 90 & 42 & 16 & 26 & 28.9 \\
Site engineer & 30 & 21 & 8 & 13 & 43.3 \\
Total & 135 & 73 & 29 & 44 & 32.6 \\
\hline
\end{tabular}

Table 5 AHP Questionnaire and classification of respondents' experiences

\begin{tabular}{llllll}
\hline Years of Experience & Project managers & Planning engineer & Site engineer & Total & $\%$ \\
\hline$<10$ years & 2 & 14 & 9 & 25 & 34.25 \\
$\geq 10$ years and $<20)$ & 5 & 21 & 7 & 33 & 45.21 \\
$\geq 20$ years & 3 & 7 & 5 & 15 & 20.55 \\
\hline
\end{tabular}

\section{AHP steps:}

Since the research objective is to develop QIPPP model, the proposed model is depicted as following:

I) Establish objective: The objective of using AHP is to give weights to each model factor to develop the quality index of preconstruction project planning.

II) Identify factors affecting preconstruction project planning: The model starts with identifying all factors affecting preconstruction project planning, based on the literature review and after determining the most important factors shown in Table 3.

III) Structure the decision hierarchy: These criteria are then structured into a hierarchy descending from an overall objective to general criteria and sub-criteria in successive levels.

IV) Compute priority weights (using AHP): After responses are sent back from experts, AHP analysis is applied for the 44 completed questionnaires as the sample pair wise matrix shown in Table 6 . Acceptable Consistency Ratio (CR) values for different matrices' sizes are; 0.05 for a $3 \times 3$ matrix, 0.08 for a $4 \times 4$ matrix, and 0.1 for larger matrices. ${ }^{21}$ A sample of those calculations is shown in Table 7. Summary of priorities of criteria and sub-criteria of the 44 completed questionnaires is shown in Table 8. As shown in Table 8 , the company category is the most effective category in PCPP with weight equal (0.34). The "resource capacity" is the most effective factor in this category with weight equal (0.45). On the other hand, the least effective category is "site conditions" with weight equal $(0.15)$. The "late material delivery" is the most effective factor in this category with weight (0.41). "Project" category and "engineering staff" category has almost the same weight equal (0.26) and (0.25), respectively. It is clear that the "project scope definition" is the most effective factor in "project" category with weight equal (0.34). In "engineering staff category", "experience and intuition of the project team members" and "clear understanding of the project scope" represent about $50 \%$ of the weight of this category. After obtaining all weights for main categories and subcategories (factors that affect preconstruction project planning) as shown in Table 8, the QIPPP is now ready to be developed. 
Table 6 Example of pair wise comparison scale of main category

\begin{tabular}{lllll}
\hline Factor & C1 & C2 & C3 & C4 \\
\hline C1 (company) & 1 & 0.33 & 3 & 3 \\
C2 (project) & 3 & 1 & 5 & 5 \\
C3 (engineering staff) & 0.33 & 0.2 & 1 & 1 \\
C4 (site) & 0.33 & 0.2 & 1 & 1 \\
Total & 4.77 & 1.73 & 10 & 10 \\
\hline
\end{tabular}

Table 7 Calculation of priority weights of main category

\begin{tabular}{|c|c|c|c|c|c|c|c|}
\hline Factor & $\mathrm{C} 1$ & $\mathrm{C} 2$ & $\mathrm{C} 3$ & $\mathrm{C4}$ & Total & Weight & C Measure \\
\hline C1 (company) & 0.21 & 0.19 & 0.3 & 0.3 & 1.01 & 0.25 & 4.04 \\
\hline C2 (project) & 0.64 & 0.58 & 0.5 & 0.5 & 2.22 & 0.55 & 4.1 \\
\hline C3 (engineering staff) & 0.07 & 0.12 & 0.1 & 0.1 & 0.39 & 0.1 & 4.02 \\
\hline C4 (site) & 0.07 & 0.12 & 0.1 & 0.1 & 0.39 & 0.1 & 4.02 \\
\hline Total & 1 & 1 & 1 & 1 & 4 & 1 & \\
\hline Consistency Index (CI) & & & & & & & 0.01 \\
\hline Random Index (RI) & & & & & & & 0.9 \\
\hline Consistency Ratio (CR) & & & & & & & 0.02 \\
\hline $\mathrm{CR}<0.1 \quad \mathrm{OK}$ & & & & & & & \\
\hline
\end{tabular}

Table 8 Summary of weights of main category and sub-category

\begin{tabular}{|c|c|c|}
\hline Categories and factors & Category weight & Factor weight \\
\hline C1 (Company) & 0.34 & \\
\hline F1 (Financial capacity) & & 0.26 \\
\hline F2 (Select team members) & & 0.29 \\
\hline F3 (Resource capacity) & & 0.45 \\
\hline C2 (Project) & 0.26 & \\
\hline F4 (Scope definition) & & 0.34 \\
\hline F5 (Complexity) & & 0.21 \\
\hline F6 (Past experience from last $\mathrm{s}$ & & 0.24 \\
\hline F7 (Financial analysis) & & 0.21 \\
\hline C3 (Engineering staff) & 0.25 & \\
\hline \multicolumn{2}{|c|}{ F8 (Clear understanding of the project scope) } & 0.25 \\
\hline \multicolumn{2}{|c|}{ F9 (Accurate work flow planning) } & 0.2 \\
\hline \multicolumn{2}{|c|}{ F10 (Clear process of project control) } & 0.17 \\
\hline \multicolumn{2}{|c|}{ F11 (Clear change request protocol) } & 0.09 \\
\hline \multicolumn{2}{|c|}{ F12 (Experience and intuition of the project team members) } & 0.28 \\
\hline C4 (Site) & 0.15 & \\
\hline F13 (Resource availability) & & 0.3 \\
\hline F14 (Late material delivery) & & 0.41 \\
\hline F15 (Bad weather conditions) & & 0.29 \\
\hline
\end{tabular}




\section{Developing a deterministic QIPPP model:}

The general equation of the QIPPP model is shown in Equation (1)

$$
\mathrm{QIPPP}=\sum_{i=1}^{n} F_{i} \times w_{i}
$$

Where; QIPPP=quality index for preconstruction project planning, $\mathrm{f}=$ factor affecting preconstruction project planning, $\mathrm{w}=$ weight of preconstruction project planning factor, and $n=$ number of preconstruction project planning factor in the model. Using factors weights developed from AHP, the quality index for preconstruction project planning model is shown in Equation (2) where Equation (2) represents the deterministic model:

$$
\begin{aligned}
& \text { QIPPP }=0.34 *[(0.26 * \mathrm{~F} 1)+(0.29 * \mathrm{~F} 2)+(0.45 * \mathrm{~F} 3)] \\
& +0.26 *[(0.34 * \mathrm{~F} 4)+(0.21 * \mathrm{~F} 5)+(0.24 * \mathrm{~F} 6)+(0.21 * \mathrm{~F} 7)] \\
& +0.25 *[(0.25 * \mathrm{~F} 8)+(0.20 * \mathrm{~F} 9)+(0.17 * \mathrm{~F} 10)+(0.09 * \mathrm{~F} 11) \\
& +(0.28 * \mathrm{~F} 12)]+0.15 *[(0.30 * \mathrm{~F} 13)+(0.41 * \mathrm{~F} 14)+(0.29 * \mathrm{~F} 15)]
\end{aligned}
$$

To convert the value of QIPPP into the percentage of Error In Plan (EIP \%), Equation (3) is utilized taking into consideration that the relation between QIPPP and EIP in this research is assumed to be linear Figure 1.

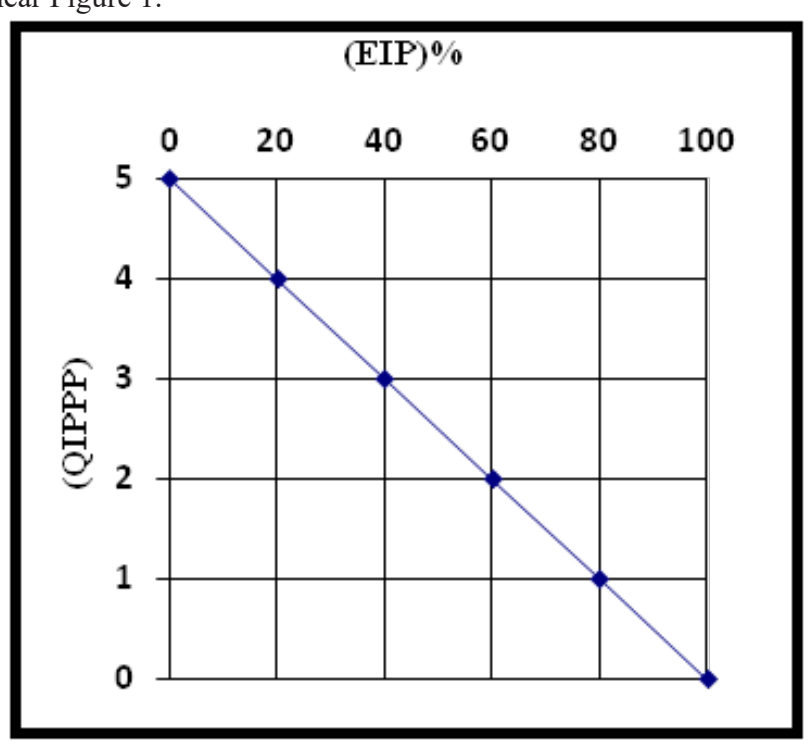

Figure I Relation between QIPPPP and EIP\%.

From Figure1 EIP could be obtained from Equation (3):

$$
\operatorname{EIP}(\%)=20 *(5-Q I P P P)
$$

\section{Determining factors scores}

To evaluate a project plan, the user should substitute F1, F2, F3 and F15 in Equation (2) with relevant scores obtained from Table 1 (A) (Appendix). The resulted value of QIPPP should range between 0 and 5. A quick look at Table A-1 reveals that 53.3\% and $46.6 \%$ of factors having scores ranging between (0-5) and have scores $(0$ or 5), respectively. For example, the financial capacity factor's score ranges from $0-5$, the user choose the score corresponding to the percentage shown in factor limitation column in Table 1(A). Let's assume the company financial capacity will cover $60-80 \%$ of project cost, the corresponding factor score $=4$. Another example, the score of "past experience from the last similar projects" ranges between
$0-5$. The user should select the score corresponding to the number of similar projects completed in the past. If the number of similar projects equals 7 projects, the corresponding score equals 3 . To more explain the process, consider one more example. The late material delivery factor's score should be selected either 0 or 5 relative to the chosen criteria from factor limitation column. If the user selects to ignore "late material delivery", then the score $=0$. After substituting all factors in Equation (2) with relevant scores, QIPPP is easy to calculate using simple math.

\section{Plan evaluation}

To interpret the QIPPP value obtained from Equation (2), first use Equation (3) to calculate the percentage of errors in plan (EIP), which defined as the percentage of mismatching between the plan at the preconstruction phase and actual values after project completion. Second, use the calculated EIP in Figure 2 to obtain the plan evaluation. For example, if QIPPP equals 1.5 and EIP equals (70\%), this plan is evaluated as (poor plan) using Figure 2. In which case, it is necessary to go back to the plan and try to improve it by focusing on factors that affect preconstruction project planning.

\section{Developing a fuzzy QIPPP model}

\section{Fuzzy logic (FL)}

The word "fuzzy" is defined as "blurred, indistinct, vaguely", according to the dictionary, The term "fuzzy logic" means to the logic of approximation. Lotfi Zadeh is considered the father of fuzzy set theory where the concept of Fuzzy Logic (FL) was first conceived in Lotfi Zadeh's proposal of fuzzy set theory. ${ }^{22}$ There are many applications depend on fuzzy logic such as decision-support systems medical applications, instrumentation, industrial process control, and robotics. ${ }^{23} \mathrm{FL}$ provides a simple method to define a conclusion based upon imprecise, vague, ambiguous, noisy, or missing input information; in addition, FL is a mathematical tool for dealing with uncertainty Sivanandam et al. ${ }^{24}$ Moreover, FL approach mimics how a person would make decisions to control problems, only much faster. ${ }^{25}$ If-Then rule statements are utilized to formulate the conditional statements that develop FL rules base system. A single fuzzy If-Then rule can be represented by the following:

If $<$ fuzzy proposition ( $\mathrm{x}$ is $\mathrm{A}_{1}$ ) $>$ Then $<$ fuzzy proposition ( $\mathrm{y}$ is $\left.\mathrm{B}_{2}\right)>$ Where $\mathrm{x}$ is an input parameter and $\mathrm{A}^{1}$ is an MF of $\mathrm{x}$, and $\mathrm{y}$ is an output parameter and $B_{2}$ is an MF of $y$. Rule-based systems are systems that have more than one rule to represent human logic and experience to the developed system. Aggregation of rules is the process of developing the overall consequent from the individual consequents added by each rule. ${ }^{24}$

As shown example in Figure 1, there are two parameters $X_{1}$ and $X_{2}$ where $\mu X_{1}=\left\{a_{1}, b_{1}, c_{1}, d_{1}\right\}, \mu X_{2}=\left\{a_{2}, b_{2}, c_{2}, d_{2}\right\}, \mu Y=\left\{a_{y}, b_{y}, c_{y}, d_{y}\right\}$ and the fuzzy system consists of two rules as following:

$$
\text { Rule 1: IF } x_{1} \text { is } a_{1} \text { AND } x_{2} \text { is c THEN } y \text { is } a_{y} \text {. }
$$$$
\text { Rule 2: IF } x_{1} \text { is } b_{1} \text { AND } x_{2} \text { is } d_{2} \text { THEN } y \text { is } b_{y} \text {. }
$$

Where two inputs are used $\left\{X_{1}=4, X_{2}=6\right\}$. Such two inputs intersect with the antecedents MF of the two rules where two consequents rules are produced $\{R 1$ and $R 2\}$ based on minimum intersections. The consequent rules are aggregated based on maximum intersections where the final crisp value is 3 . The aggregated output for $R_{i}$ rules are given by 


\section{Rule 1: $\mu R 1=\min [\mu a 1(x 1)$ and $\mu c 2(x 2)]$ \\ Rule 2: $\mu R 2=\min [\mu b 1(x 1)$ and $\mu d 2(x 2)]$ \\ $Y$ : Fuzzification [max [R1, R2]}

Fuzzification is converting a numeric value (or crisp value) into a fuzzy input. Conversely, defuzzification is the opposite process of fuzzification where the defuzzification is the conversion of a fuzzy quantity into a crisp value. Max-membership, the center of gravity, weighted average, mean-max; different defuzzification and center of sums are different defuzzification methods. ${ }^{26}$

\section{Fuzzy model past practices}

Yasin $\operatorname{Karatas}^{27}$ have developed a reliable fuzzy expert tool for small satellite cost estimation the model consists of three variables where cost is a dependent variable whereas weight, and resolution are independent variables. The input values were from 50 to $500 \mathrm{~kg}$ for weight and from $1 \mathrm{~m}$ to $20 \mathrm{~m}$ for resolution and output values between \$1 million and \$200 million for cost; this model provides an expert assistance to decision making under uncertainty for small satellite cost estimation. Bhatnagar \& Ghose ${ }^{28}$ concluded that fuzzy logic is the best model for predicting early stage effort estimation, where Mamdani FIS was more efficient than neural network models to predict the early stage efforts. Cheng ${ }^{29}$ have applied the evolutionary fuzzy neural inference for a conceptual cost estimate model, an evolutionary web-based conceptual cost model has been developed which can be used to estimate conceptual construction cost more precisely at the early stages of projects. Adeli \& Jiang ${ }^{30}$ have developed a neurofuzzy logic model to estimate the freeway work zone capacity that provides a more accurate estimate of the work zone capacity. Nabil El Sawalhi \& Nedal Salah, ${ }^{31}$ have developed a parametric fuzzy cost model to predict the conceptual cost of construction building projects in Gaza Strip. The results provided the ability of FL model to predict cost estimate to an acceptable degree of accuracy reached to $88 \%$. Therefore, it is recommended that the fuzzy logic model will provide more accurate estimates, save time, minimize error and provide taking decisions under uncertainty.

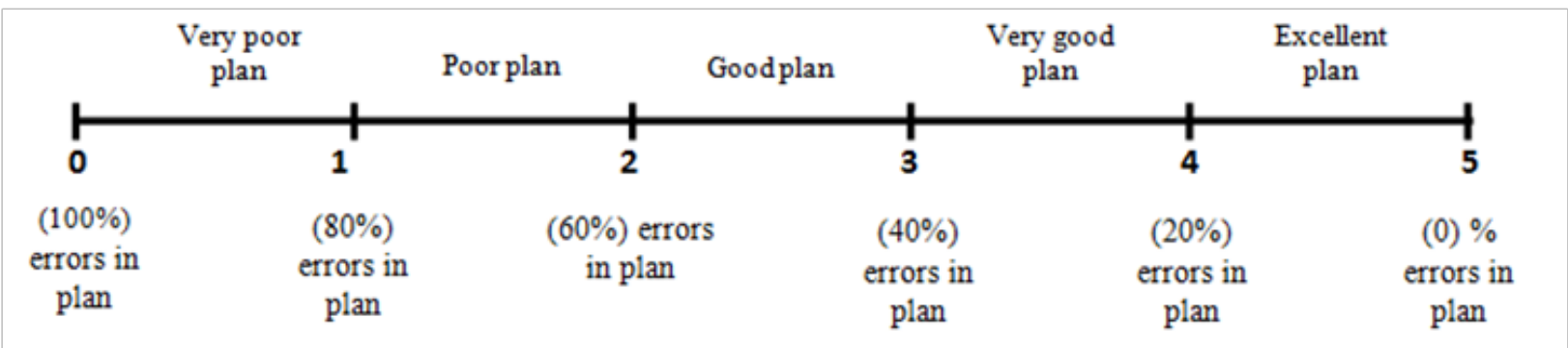

Figure 2 The quality index for preconstruction project planning.

\section{Fuzzy model development}

The objective of the fuzzy model is to provide uncertainty concept to QIPPP and to improve the accuracy of the deterministic model. This study has developed two fuzzy models where both models depend on fuzzy set theory with a different internal design of the proposed model. These modes are a fuzzy summation model and a fuzzy-fuzzy model.

\section{Fuzzy summation model}

This model is a fuzzy model that uses the fifteen screened factors of QIPPP as model's inputs and the output would be a QIPPP. It is difficult to convert all fifteen factors of QIPPP to a just one fuzzy model because it requires huge number of fuzzy rules. Therefore, the model design divides the fifteen factors into four groups based on its categories. These categories have been mentioned in Table 8. As a result, four fuzzy sub-models (FSMSs) have been developed (FSM $\mathrm{C} 1$, FSM C2, FSM C3 and FSM C4) and then have been summed to calculate QIPPP as illustrated in Table 9. Figure 3 shows the input factors and output $\mathrm{C} 1$ of the first FSM C1. In this research, the membership values and the membership functions to fuzzy variables were assigned by intuition. It is based on the authors' own intelligence and understanding of the case study attributes. The most common types of membership functions are triangular. As a result, Triangular membership functions have been applied to develop the FSM in this research. As illustrated in Figure 4, F1 has been divided into six triangular memberships ranging from zero to five. Similarly, F2, F3, F4 and C1 have been created. The next step is to define fuzzy rules as illustrated in Figure 5. Similarly, (C2, C3 and C4) FSMs can be developed. Once these sub-models have been created, the QIPPP value can be predicted.

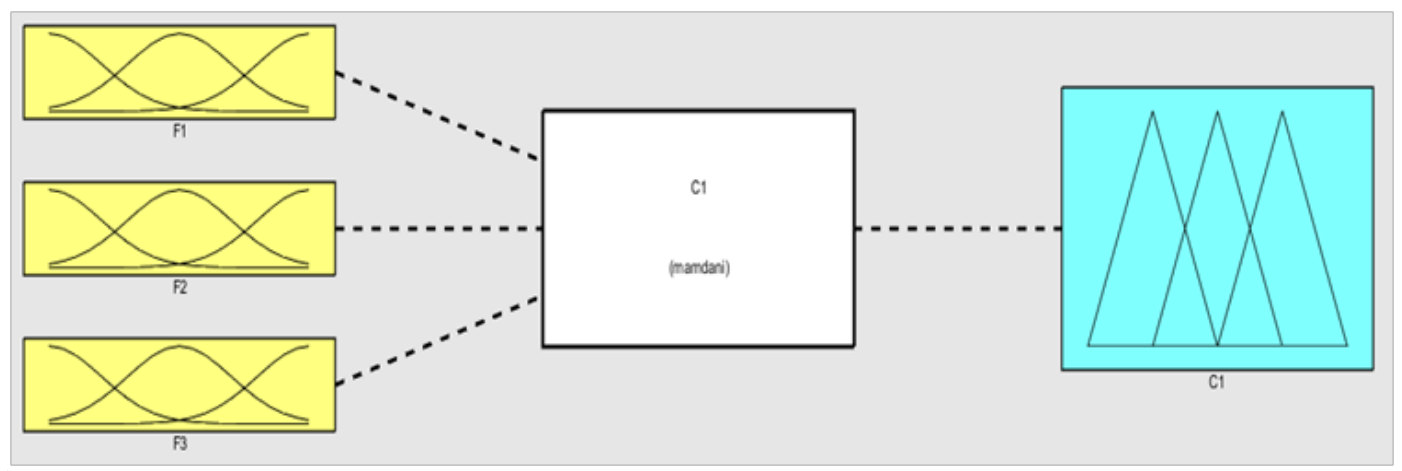

Figure $3 \mathrm{FSM} \mathrm{C} 1$ components. 


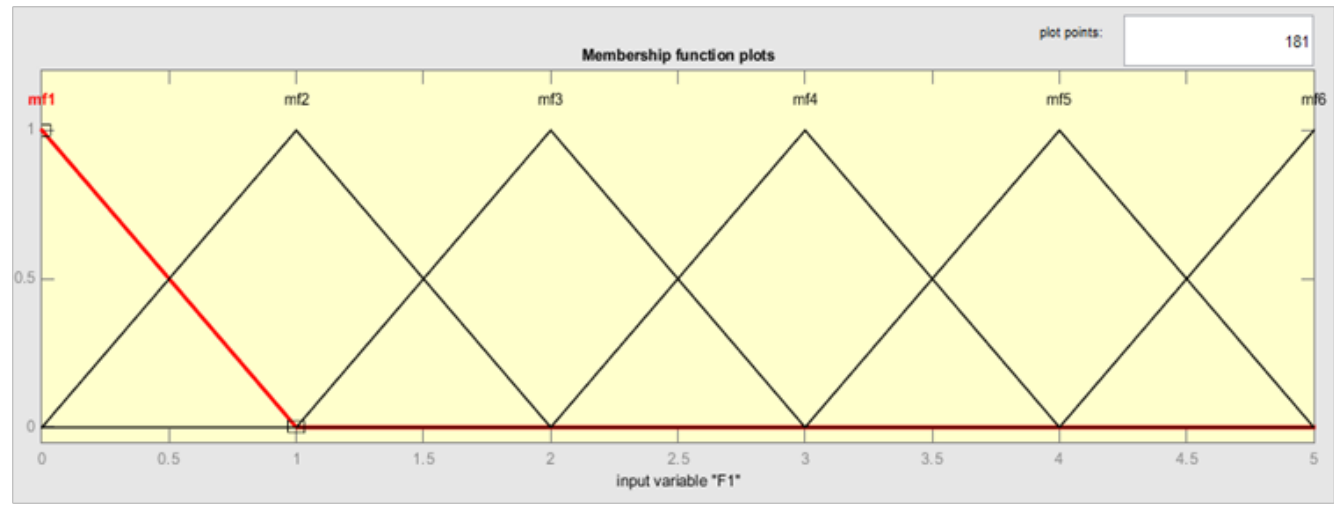

Figure 4 Triangular membership functions of FI.

\begin{tabular}{|c|c|c|c|c|c|}
\hline A & & Rule Editor: C1 & - & $\square$ & $\mathrm{x}$ \\
\hline File & Edit View & Options & & & \\
\hline
\end{tabular}

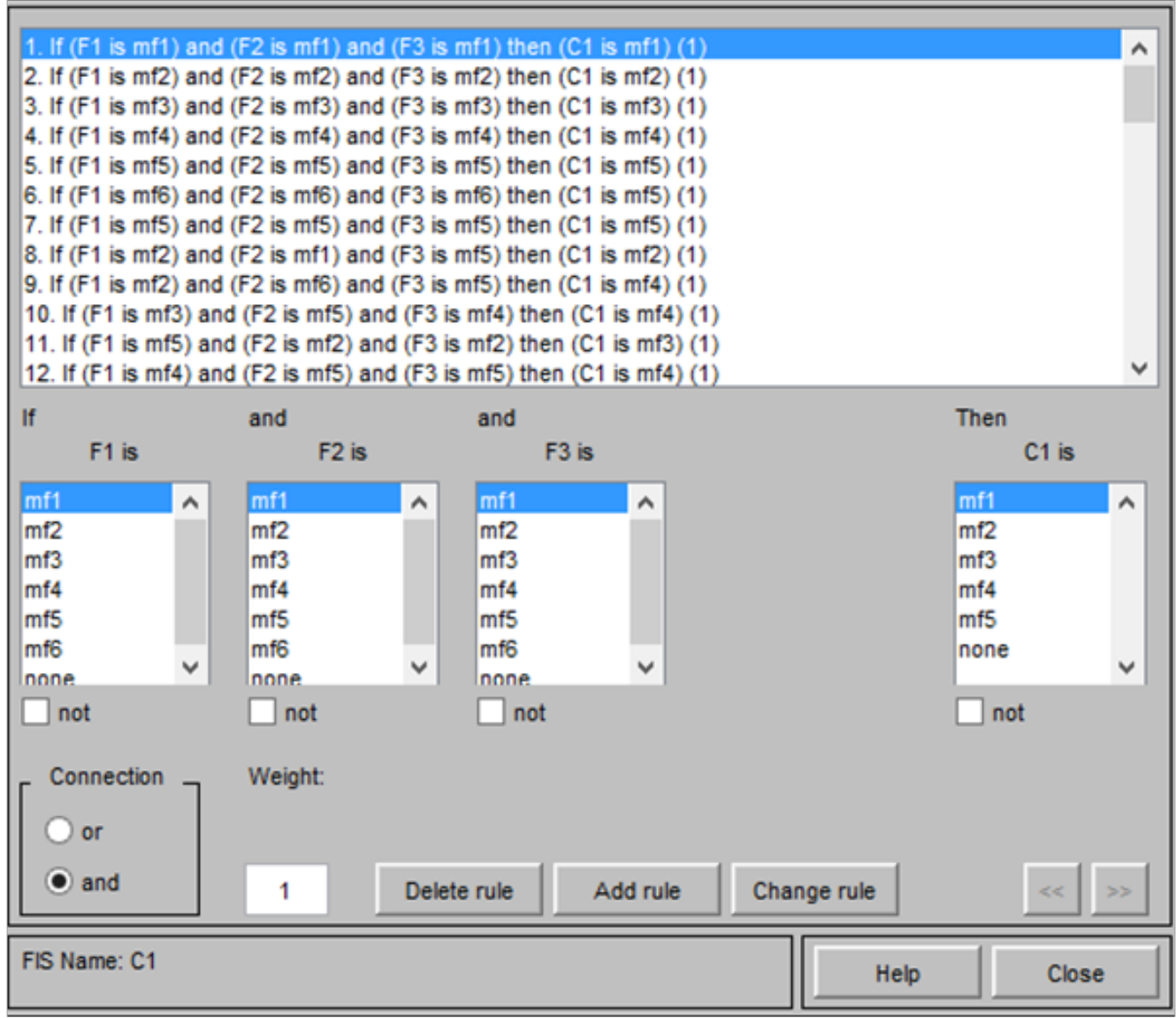

Figure 5 fuzzy rules of FSM CI.

Table 9 Factors used in each model

\begin{tabular}{lll}
\hline Serial & Model & Factors used in each model \\
\hline 1 & FSM C1 & $0.34^{*}\left[\left(0.26^{*} \mathrm{~F} 1\right)+(0.29 * \mathrm{~F} 2)+\left(0.45^{*} \mathrm{~F} 3\right)\right]$ \\
2 & FSM C2 & $0.26^{*}[(0.34 * \mathrm{~F} 4)+(0.21 * \mathrm{~F} 5)+(0.24 * \mathrm{~F} 6)+(0.21 * \mathrm{~F} 7)]$ \\
3 & FSM C3 & $0.25^{*}\left[(0.25 * \mathrm{~F} 8)+(0.20 * \mathrm{~F} 9)+(0.17 * \mathrm{~F} 10)+(0.09 * \mathrm{~F} 11)+\left(0.28^{*} \mathrm{~F} 12\right)\right]$ \\
4 & FSM C4 & $0.15 *[(0.30 * \mathrm{~F} 13)+(0.41 * \mathrm{~F} 14)+(0.29 * \mathrm{~F} 15)]$ \\
5 & QIPPP & {$[\mathrm{FSM} \mathrm{C} 1+\mathrm{FSM} \mathrm{C} 2+\mathrm{FSM} \mathrm{C} 3+\mathrm{FSM} \mathrm{C} 4]$} \\
\hline
\end{tabular}




\section{Fuzzy-fuzzy model}

The Fuzzy-Fuzzy model (FFM) consists of two successive fuzzy models, the first model is a just fuzzy summation model, whereas the second model is a fuzzy model that converts the output crisp values of (FSM C1, FSM C2, FSM C3 and FSM C4) to fuzzy values to produce QIPPP. The objective of this model is to apply more fuzziness to QIPPP. Figure 6 shows the structure of the second model of the FFM.

Table 10 Case I fuzzy models results

\begin{tabular}{|c|c|c|c|c|c|}
\hline Case 1 inputs scores & & Category of FSMs & Crisp Values of FSMs & FFM & Crisp Value of FFM \\
\hline $\mathrm{F} 1$ & 3 & FSM C1 & 1.28 & & 3.75 \\
\hline $\mathrm{F} 2$ & 4 & & & & \\
\hline F3 & 4 & & & & \\
\hline F4 & 5 & FSM C2 & 0.65 & & \\
\hline F5 & 3 & & & & \\
\hline F6 & 4 & & & & \\
\hline F7 & 0 & & & & \\
\hline F8 & 4 & FSM C3 & 1.12 & & \\
\hline F9 & 5 & & & & \\
\hline F10 & 5 & & & & \\
\hline F11 & 5 & & & & \\
\hline F12 & 4 & & & & \\
\hline F13 & 5 & FSM C4 & 0.37 & & \\
\hline F14 & 5 & & & & \\
\hline \multirow[t]{2}{*}{ F15 } & 0 & & & & \\
\hline & & Fuzzy summation model & 3.42 & & \\
\hline
\end{tabular}

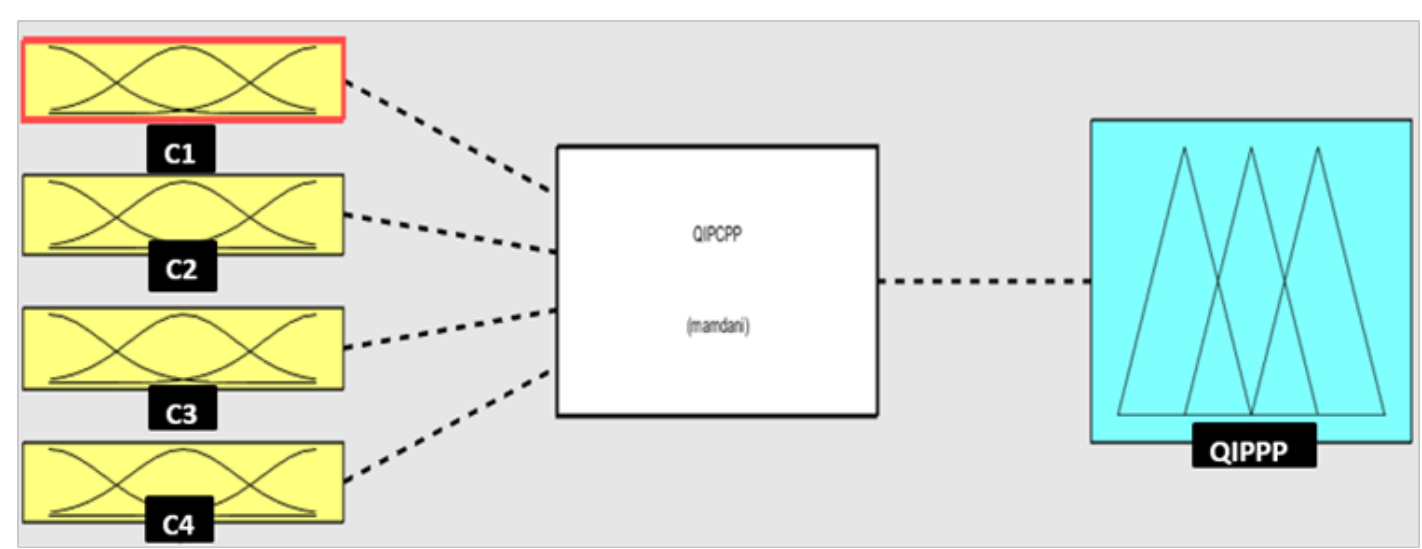

Figure 6 The structure of the FFM.

\section{Results and discussion}

\section{Model validation}

Two case studies are applied to validate model results. A planning engineer with experience exceeds 15 years is asked to score each factor. Then, QIPPP is calculated using Equation (2) for a deterministic model and by fuzzy summation model and FFM for fuzzy models. EIP\% is calculated using Equation (3). The results of case studies according to this research's model compared with the actual values for the completed project. In this research project duration is used to compare result.

\section{Case study I:}

The project is in (Malls and huge government buildings) group. The estimated duration of this project is 885 days and the actual duration is 1125 days. Table 10 illustrates the score values of the first case study and the results of fuzzy models.

\section{Case study 2:}

The project is in (Residential and administrative buildings) group. The estimated duration of this project is 240 days and the actual duration is 326 days. The detailed information that is used for the model is given as shown in Table 9. This information is translated into a chart as shown in Figure 4, Tables $11 \& 12$.

Actual error in project $=\frac{\text { Estimated duration }- \text { Actual duration }}{\text { Estimated duration }}$

Comparison error $=$ Model EIP - Atual EIP

Overall comparison error $=\frac{\mid \sum_{0}^{\mathrm{n}} \text { comparison error } \mid}{\mathrm{n}}$ 
Where:

EIP: Error in Plan.

(n) : number of cases.

Overall comparison error: the absolute average of all cases' errors to select the most accurate model.

\section{Deterministic model results (model I)}

As illustrated in Table 12, according to the case study (1), by applying the deterministic model to this case, using Equation (2), the result is 3.78 , this value is between the ranges $3: 4$ in a zone called very good plan. In this zone, the error in the plan is ranged from $20: 40 \%$.

Table I I Case 2 fuzzy models results
The EIP equals $24.40 \%$ compared with the actual error in project plan "percentage" which is measured from the difference between the estimated duration and actual duration, it is $27.1 \%$ Equation (4). The model results and the case study results have the same range (very good plan). Based on Equation (5), the comparison error is $-2.70 \%$. According to the case study (2), by applying the deterministic model to this case, using Equation (2), the result is 3.42; this value is between the ranges 3:4 in a zone called a very good plan. In this zone, the error in the plan ranged from $20 \%: 40 \%$. The EIP of the model is equal $31.6 \%$ compared with the actual error in project plan; it is $35.8 \%$ Equation (4). The model results and the case study results both have in the same range (very good plan). Based on Equation (5), the comparison error is $-4.20 \%$.

\begin{tabular}{|c|c|c|c|c|c|}
\hline Case 2 inputs scores & & Category of FSMs & Crisp Values of FSMs & FFM & Crisp Value of FFM \\
\hline $\mathrm{F} 1$ & 5 & FSM C1 & 1.5 & & 2.5 \\
\hline $\mathrm{F} 2$ & 5 & & & & \\
\hline F3 & 4 & & & & \\
\hline $\mathrm{F} 4$ & 5 & FSM C2 & 1.04 & & \\
\hline F5 & 5 & & & & \\
\hline F6 & 5 & & & & \\
\hline F7 & 1 & & & & \\
\hline F8 & 4 & FSM C3 & 0.7 & & \\
\hline F9 & 5 & & & & \\
\hline $\mathrm{F} 10$ & 0 & & & & \\
\hline F11 & 0 & & & & \\
\hline F12 & 4 & & & & \\
\hline $\mathrm{F} 13$ & 0 & FSM C4 & 0.06 & & \\
\hline F14 & 0 & & & & \\
\hline F15 & 0 & & & & \\
\hline
\end{tabular}

Fuzzy summation model $\quad 3.3$

Table I 2 Models comparisons

\begin{tabular}{|c|c|c|c|c|c|}
\hline & & & Model 1 & Model 2 & Model 3 \\
\hline & & Actual error in project & Deterministic model & Fuzzy summation model & FFM \\
\hline \multirow[t]{4}{*}{ Case 1} & QIPPP & 3.65 & 3.78 & 3.43 & 3.75 \\
\hline & EIP & 27.1 & 24.4 & 31.5 & 25 \\
\hline & Decision & very good plan & very good plan & very good plan & very good plan \\
\hline & Comparison error & 0 & -2.7 & 4.4 & -2.1 \\
\hline \multirow[t]{5}{*}{ Case 2} & QIPPP & 3.21 & 3.42 & 3.3 & 2.5 \\
\hline & EIP & 35.8 & 31.6 & 34 & 50 \\
\hline & Decision & very good plan & very good plan & very good plan & good plan \\
\hline & Comparison error & 0 & -4.2 & -1.8 & 14.2 \\
\hline & Overall error & 0 & 6.9 & 2.6 & 12.1 \\
\hline
\end{tabular}




\section{Fuzzy summation model results (model 2)}

According to the case study (1), by applying the Fuzzy summation model to this case, the result is 3.43 , as a result the decision would be a very good plan. In this zone, the EIP of the model result equals $31.50 \%$ compared with the actual error in project plan, it is $27.1 \%$ by Equation (4). The model results and the case study results have the same range (very good plan). Based on Equation (5), the comparison error is $4.40 \%$. According to the case study (2), by applying the Fuzzy summation model to this case, the result is 3.30, as a result the decision would be a very good plan. In this zone, the EIP of the model result equals $34.00 \%$ compared with the actual error in project plan, it is $35.80 \%$ by Equation (4). The model results and the case study results have the same range (very good plan). Based on Equation (5), the comparison error is $-1.80 \%$.

\section{FFM results (model 3 )}

According to the case study (1), by applying the FFM to this case, the result is 3.75 , as a result the decision would be a very good plan. In this zone, the EIP of the model result equals $25.00 \%$ compared with the actual error in project plan, it is $27.1 \%$ Equation (4). The model results and the case study results have the same range (very good plan). Based on Equation (5), the comparison error is $-2.10 \%$. According to the case study (2), by applying the FFM to this case, the result is 2.50 , as a result the decision would be a very good plan. In this zone, the EIP of the model result equals $50.00 \%$ compared with the actual error in project plan, it is $35.80 \%$ by Equation (4). The model results and the case study results have different ranges (very good plan) for the actual case study and (good plan) for FFM. Based on Equation (5), the comparison error is $14.20 \%$.

\section{Select the most precise model}

As illustrated in Table12, based on Equation (6), the overall comparison error for each model has been calculated, the worst precise model is FFM with overall error $(12.10 \%)$ due to overuse of fuzziness concept that leads to a low precise model performance. However, the Fuzzy summation model produces the best precise results $(2.60 \%)$ more than the deterministic model $(6.90 \%)$. Therefore, the correct use of fuzzy theory will develop the most accurate, realistic and reliable models than a deterministic ones. As a result, the Fuzzy summation model is the most precise model to predict QIPPP.

\section{Conclusions and recommendation}

The aim of this research is to develop a model to precisely predict the quality of preconstruction project planning to predict if the plan is good or not. This model is created by collecting factors that affect preconstruction project planning. Some filtrations are made for them in order to find the most important factors using the Delphi technique then has been applied AHP technique to find their weights. The company has the most important category with the value of $(0.34)$ while, the most effective factor in this category is the resource capacity with the value of (0.45). It is also clear that, the most important factor in project category is the project scope definition with the value of $(0.34)$ while the most important factor in the engineering staff category is the experience and intuition of the project team members with value of $(0.28)$. Finally, the most important factor in the site condition category is the late material delivery with value of $(0.41)$. Moreover, three models have been developed based on both deterministic and fuzzy concepts, and the results show that fuzzy model is more accurate and realistic than the deterministic one. Therefore, the correct use of fuzzy theory will develop the most accurate, realistic and reliable models than a deterministic ones. Finally, Fuzzy summation model is selected to be the most accurate model of QIPPP with overall error $(2.60 \%)$.

\section{Acknowledgments}

None.

\section{Conflicts of interest}

The author declares there is no conflict of interest.

\section{References}

1. Bayraktar ME, Hastak M, Gokhale S, et al. Decision tool for selecting the optimal techniques for cost and schedule reduction in capital projects. Journal of Construction engineering and management. 2011;137(9):645-655.]

2. Flyvbjerg B, Bruzelius N, Rothengatter W. Megaprojects and risk: An anatomy of ambition. Cambridge University Press. New York; 2003.

3. Son H, Lee S, Kim C. An Empirical Investigation of Key Preproject Planning Practices Affecting the Cost Performance of Green Building Projects. Procedia Engineering. 2015;118(1):37-41.

4. Senaratne S, Jayarathna T. Quality planning process of construction contractors: case studies in Sri Lanka. Journal of Construction in Developing Countries. 2012;17(1):103-115.

5. Laufer A, Tucker RL. Is construction project planning really doing its job? A critical examination of focus, role and process. Construction Management and Economics. 1987;5(3):243-266.

6. Laufer A. Decision-making roles in project planning. Journal of Management in Engineering. 1990;6(4):416-430.

7. Plumbing-Heating-Cooling Contractors (PHCC) National Association. 2002.

8. Hanna AS, Skiffington MA. Effect of preconstruction planning effort on sheet metal project performance. Journal of Construction Engineering and Management. 2010;136(2):235241.

9. Hendrickson C. Project Management for Construction, 2nd ed, Pittsburgh: Prentice Hal sited. In: Andersson C, Rosenberg $\mathrm{L}$, editors. The preconstruction planning process from a site manager perspective. 1998

10. Söderberg J Byggprocessen, Lund: Lunds tekniska högskola, Institutionen för byggnadsekonomi sited. In: Andersson C\& Rosenberg L, editors. The preconstruction planning process from a site manager perspective. 1999.

11. Gibson GE, Wang YR, Cho CS, et al. What is pre-project planning, anyway? Journal of Management in Engineering. 2006;22(1):35-42.

12. Dumont PR, Gibson GE, Fish JR. Scope management using project definition rating index. Journal of Management in Engineering. 1997;13(5):54-60.

13. Cho C, Furman J, Gibson G. Development of the project definition rating index (PDRI) for building projects. 
Research Rep, Construction Industry Institute, Austin. Tex. 1999;1(1):155-211.

14. Doloi H. Cost overruns and failure in project management: understanding the roles of key stakeholders in construction projects. Journal of construction engineering and management. 2012;139(3):267-279?

15. Son J, Rojas EM. Impact of optimism bias regarding organizational dynamics on project planning and control Journal of construction engineering and management. 2010;137(2):147-157.

16. Masmoudi M, Haït A. Project scheduling under uncertainty using fuzzy modelling and solving techniques. Engineering Applications of Artificial Intelligence. 2013;26(1):135-149.

17. Nair R, Aggarwal R, Khanna D. Methods of formal consensus in classification/diagnostic criteria and guideline development. Seminars Arthritis Rheumatism. 2011;41(2):95-105.

18. Clayton MJ. Delphi: a technique to harness expert opinion for critical decision making tasks in education. Educational Psychology. 1997;17(4):373-386.

19. Saaty TL. Axiomatic foundation of the analytic hierarchy process. Management science. 1986;32(7):841-855.

20. Saaty TL. The Analytic Hierarchy Process. McGraw-Hill. New York. 1980;9(3-5):161-176.

21. Saaty Thomas L. Fundamentals of decision making with the analytic hierarchy process. PA: RWS Publications. 1994.

22. Zadeh LA. Fuzzy sets. Information and Control. 1965;8(3):338353.
23. Idri A, Abran A, Khoshgoftaar k. Fuzzy case-based reasoning models for software cost estimation. Soft Computing in Software Engineering. 2001;1(1):64-96.

24. Sivanandam S, Sumathi S, Deepa S. Introduction to Fuzzy Logic using MATLAB. Springer-Verlag Berlin Heidelberg. 2007.

25. Simon D. Introduction to fuzzy control. Courtesy of Embedded Systems Programming. 2003.

26. Siddique N, Adeli H. Computational intelligence: synergies of fuzzy logic, neural networks and evolutionary computing. John Wiley \& Sons. 2013.

27. Karatas Y, Ince F. Feature article: Fuzzy expert tool for smal satellite cost estimation. IEEE Aerospace and Electronic Systems Magazine. 2016;31(5):28-35.

28. Bhatnagar R, Ghose M. Comparing soft computing techniques for early stage software development effort estimations. International Journal of Software Engineering \& Applications. 2012;3(2):1-9.

29. Cheng M, Tsai H, Hsieh W. Web-based conceptual cost estimates for construction projects using evolutionary Fuzzy Neural Inference Model. Automation in Construction Journal. 2009;18(2): 164-172.

30. Adeli H, Jiang X. Neuro-Fuzzy Logic Model for freeway work zone capacity estimation. Journal of Transportation Engineering. 2003;129(5):484-493.

31. Nabil El Sawalhi, Nedal Salah Jameel. Cost Estimation of Construction Projects at Gaza Strip Using Fuzzy Logic. The Islamic University of Gaza-Palestine. 2013. 